\title{
Ephemeroptera, Plecoptera and Trichoptera assemblages in two Atlantic Rainforest streams, Southeastern Brazil
}

\author{
Vera L. Crisci-Bispo ${ }^{1}$; Pitágoras C. Bispo ${ }^{1} \&$ Claudio G. Froehlich ${ }^{2}$ \\ ${ }^{1}$ Laboratório de Biologia Aquática, Departamento de Ciências Biológicas, Universidade Estadual Paulista. Avenida Dom \\ Antônio 2100, Caixa Postal 65, 19806-900 Assis, São Paulo, Brasil. E-mail: crisci@usp.br; pitagoras@assis.unesp.br \\ 2 Departamento de Biologia, Universidade de São Saulo. Avenida Bandeirantes 3900, 14040-901 Ribeirão Preto, São Paulo, \\ Brasil.E-mail: cgfroeh@usp.br
}

\begin{abstract}
Assemblages of Ephemeroptera, Plecoptera and Trichoptera (EPT) of rocky substrates were studied in two streams of the Intervales State Park. Monthly collections with a Surber sampler (10 random sampling units, $1 \mathrm{~m}^{2}$ ) were carried out from September 1999 to September 2000 and quarterly from December 2000 to September 2001 in the Bocaina and Água Comprida Streams. The EPT fauna in the Bocaina Stream was more diversified and more abundant than in the Água Comprida Stream. The EPT fauna was quite different in the two streams both in composition as in functional aspects. The results of this study indicate that there was not a clear seasonal pattern in the temporal variation of density.
\end{abstract}

KEY WORDS. Aquatic insects; diversity; EPT; lotic environments.

RESUMO. Comunidades de Ephemeroptera, Plecoptera e Trichoptera em dois ribeirões de Mata Atlântica do Sudeste do Brasil. Comunidades de Ephemeroptera, Plecoptera e Trichoptera (EPT) em substrato rochoso foram estudadas em dois riachos do Parque Estadual Intervales. Coletas com um amostrador de Surber (10 subamostras aleatórias, $1 \mathrm{~m}^{2}$ ) foram feitas mensalmente de setembro de 1999 a setembro de 2000 e trimestralmente de dezembro de 2000 a setembro de 2001 nos Ribeirões Bocaina e Água Comprida. A fauna de EPT do Ribeirão Bocaina foi mais diversificada e mais abundante do que a do Ribeirão Água Comprida. A fauna de EPT foi bastante diferente entre os dois riachos, tanto do ponto de vista da composição faunística quanto do ponto de vista funcional. Os resultados indicaram que não houve um padrão sazonal claro da variação temporal da densidade.

PALAVRAS-CHAVE. Ambientes lóticos; diversidade; EPT; insetos aquáticos.

Aquatic insects are important elements in the ecological dynamics of lotic environments. In recent years, the interest in the study of these insects has grown mainly due to their utilization in environmental monitoring, since many of them are sensitive to environmental disturbances (Rosenberg \& RESH 1993, Navas-Pereira \& Henrique 1996). Among the aquatic insects of low and medium order streams in mountainous regions, Ephemeroptera, Plecoptera and Trichoptera (EPT) are usually abundant and highly diversified. In Brazil, studies on the EPT fauna have intensified from the late nineties on, improving the knowledge about them (Froenlich \& Oliveira 1997, Oliveira \& Froenlich 1997a, Oliveira et al. 1997, Bispo \& Oliveira 1998, Diniz-Filho et al. 1998, Bispo et al. 2001). Marchant et al. (1995) suggest that as the EPT fauna represents well the ecological patterns of all the macroinvertebrate community, the studies could be centered in these orders.

As benthic organisms present, on the whole, low mobility, in this way, local conditions, such as degree of canopy cover, declivity, hydraulics, environmental heterogeneity, frequency of disturbances, may be very important in structuring their communities (Bispo \& Oliveira 1998, Diniz-Filho et al. 1998, Bispo et al. 2004). Keeping this in mind, the aim of this study was to investigate the structure of EPT assemblages in two streams with differences in declivity, heterogeneity and canopy cover. In addition, the temporal variation of density in the two streams was also investigated.

\section{MATERIAL AND METHODS}

\section{Study area}

This study was carried out in two streams of the Intervales State Park. The Park is located in the Serra de Paranapiacaba, South of the State of São Paulo, and includes areas of the municipalities of Ribeirão Grande, Eldorado, Guapiara, Iporanga and Sete Barras. The Park is situated at latitudes $24^{\circ} 12^{\prime}-24^{\circ} 25^{\prime} \mathrm{S}$ and $48^{\circ} 03^{\prime}-48^{\circ} 30^{\prime} \mathrm{W}$. Its area is approximately $380 \mathrm{~km}^{2}$ and it represents one of the last well-preserved areas of the Atlantic Forest. Altitudes vary from 70 to $1000 \mathrm{~m}$. The highest ridges define the watershed between the Ribeira de Iguape River catch- 
ment in the direction of the coast and the Paranapanema River catchment flowing inland. As concerns the hydrological classification, within the Park the rivers vary from first to $5^{\text {th }}$ order. It rains along all the year and this promotes high air humidity.

\section{Collection and identification}

This study was carried out in the Bocaina Stream (Station 1: $24^{\circ} 16^{\prime} 13^{\prime \prime} \mathrm{S}$ and $\left.48^{\circ} 27^{\prime} 09^{\prime \prime} \mathrm{W}\right)$ and the Água Comprida Stream (Station 2: $24^{\circ} 17^{\prime} 38^{\prime \prime} S$ and $48^{\circ} 25^{\prime} 04^{\prime \prime} \mathrm{W}$ ). The Bocaina Stream is $2^{\text {nd }}$ order, with a dense canopy cover, presence of riffles and pools, and common litter accumulations. The Água Comprida Stream is $3^{\text {rd }}$ order, with a partially open canopy cover, with a high declivity and the consequent higher water speed, pools are scarce. In this study, the classification of stream order of STrahler (1957) was followed. During collections, the following environmental factors were registered: air and water temperatures $\left({ }^{\circ} \mathrm{C}\right.$, alcohol thermometer), water speed $(\mathrm{m} / \mathrm{s}$, floater method), discharge $\left(\mathrm{m}^{3} / \mathrm{s}\right.$, according to the methodology described in LiND 1979), electric conductivity $(\mu \mathrm{S} / \mathrm{cm})$, hydrogenionic potential $(\mathrm{pH})$, water turbidity (NTU) and dissolved oxygen $(\mathrm{mg} / \mathrm{l})$, the last four measured with portable meters. The characterization of the two stations is presented in table I. Precipitation data were obtained in the "Departamento de Águas e Energia Elétrica" of the State of São Paulo (DAEE).

Each of the two streams was sampled monthly from September 1999 to September 2000. From December 2000 to September 2001 quarterly samplings were carried out. In each of the collections, 10 random sampling units were collected in riffles with rocky bottom with a Surber sampler, totalling $1 \mathrm{~m}^{2}$.

The Ephemeroptera, Plecoptera and Trichoptera immatures were sorted out and identified to genus. For this, the following keys were used: Domínguez et al. (1992) for Ephemeroptera, Benedetto (1974) and Froenlich (1984) for Plecoptera, and Angrisano (1995) and Wiggins (1998) for Trichoptera. The EPT genera were included in the functional feeding categories proposed by Cummins \& KLUG (1979) using data from the literature (Merritt \& Cummins 1996, Wiggins 1998, Polegatto \& Froenlich 2003) and observations in the field. The trophic functional categories considered were collectors, scrapers, shredders and predators.

\section{Data analysis}

Diversity was evaluated using the Shannon-Wiener Diversity Index $\left(\mathrm{H}^{\prime}=-\Sigma \mathrm{p}_{\mathrm{i}} \ln \mathrm{p}_{\mathrm{i}}\right)$ and Pielou Evenness Index $\left(\mathrm{E}=\mathrm{H}^{\prime} / \ln S\right)$, where $p_{i}=n_{i} / N, n_{i}$ abundance of the taxon $i, N$ total abundance and $S$ richness. In the case of the Shannon-Wiener index, a t test was made using the Hutcheson method (Magurann 1989) to compare the diversity between the two streams. Additionally, richness was evaluated by rarefaction curves (Hulbert 1971, SimBERLOFF 1972) using a Monte Carlo permutation method. To estimate the number of taxa for $\mathrm{k}$ individuals, $\mathrm{k}$ individuals were randomly withdrawn from the sample and the observed number of taxa was registered. That procedure was repeated 1000 times. The procedures were carried out using the Ecosim 5 simulation program (Gotelli \& ENTSMinger 2000).

The logarithmized abundance matrix $[\log (x+1)]$ was submitted to the Detrended Correspondence Analysis (DCA) ordering the observations (months) and the variables (taxa). DCA was carried out using the PC-ORD 4.0 program (McCune \& MefFord 1999).

The logarithmized matrix was also used to calculate a similarity matrix among the samples (Q mode), using the MorisitaHorn Index (Horn 1966, KreBs 1999). Visualization of that matrix was obtained through an agglomerative cluster analysis (ROMESBURG 1984). UPGMA was used to obtain the dendrogram (KREBs 1999). The dendrogram distortion was evaluated by the cophenetic correlation coefficient (RomesBurg 1984). That coefficient was obtained correlating the original similarity matrix with the matrix obtained from the dendrogram; $r \geqslant 0.8$ is considered a good value (Rohlf 2000). The cluster analysis was carried out using the NTSYS 2.1 program (Rohlf 2000).

\section{RESULTS}

Figure 1 shows the average monthly precipitation ( $\mathrm{mm}$ ) from 1990 to 2001 for the Intervales State Park. Historically, the data show that lower precipitations occurred between May

Table I. Mean and standard deviation (SD) of abiotic factors of the Bocaina and Água Comprida streams recorded monthly from Setember 1999 to Setember 2000 and quarterly from December 2000 to June 2001, Intervales State Park, São Paulo.

\begin{tabular}{|c|c|c|c|c|}
\hline \multirow{2}{*}{ Abiotic fators } & \multicolumn{2}{|c|}{ Bocaina Stream } & \multicolumn{2}{|c|}{ Água Comprida Stream } \\
\hline & Mean & SD & Mean & SD \\
\hline Air Temperature $\left({ }^{\circ} \mathrm{C}\right)$ & 15.810 & 3.680 & 17.580 & 3.290 \\
\hline Water Temperature $\left({ }^{\circ} \mathrm{C}\right)$ & 17.300 & 4.320 & 19.350 & 3.270 \\
\hline Water Velocity $(\mathrm{m} / \mathrm{s})$ & 0.326 & 0.080 & 0.524 & 0.161 \\
\hline Discharge $\left(\mathrm{m}^{3} / \mathrm{s}\right)$ & 0.194 & 0.168 & 0.343 & 0.176 \\
\hline $\mathrm{pH}$ & 7.840 & 0.430 & 8.030 & 0.340 \\
\hline Electrical Conductivity $(\mu \mathrm{S} / \mathrm{cm})$ & 113.250 & 24.990 & 148.910 & 16.280 \\
\hline Dissolved Oxigen (mg/l) & 8.360 & 1.090 & 8.310 & 1.320 \\
\hline Water Turbidity (NTU) & 4.550 & 3.440 & 7.560 & 6.420 \\
\hline
\end{tabular}



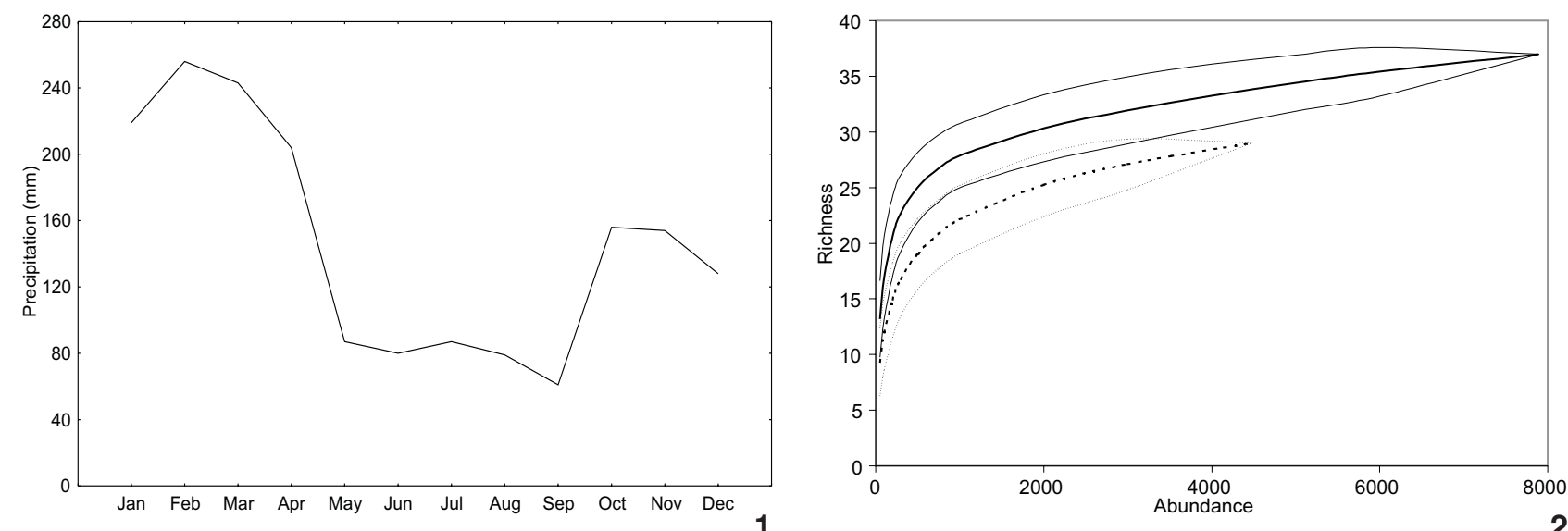

Figures 1-2. (1) Average monthly rainfall from 1990 to 2001 in the Intervales State Park; (2) rarefaction curves of immatures of genera of Ephemeroptera, Plecoptera and Trichoptera collected monthly from September 1999 to September 2000 and quarterly from December 2000 to September 2001 in Bocaina and Água Comprida Streams, Intervales State Park, São Paulo. Bocaina Stream (continuous line); Água Comprida Stream (dashed line).

and September, and that the rainiest month is February. These data also show that rainfall in the less rainy months was approximately $50 \mathrm{~mm}$. Precipitation data referring to the period of the study were unavailable.

Table II lists the total EPT taxa collected monthly from September 1999 to September 2000 and quarterly from December 2000 to September 2001 in the Bocaina and Água Comprida Streams. The EPT fauna in the Bocaina Stream was more diversified and abundant than in the Água Comprida Stream (Tab. II). The Shannon-Wiener diversity and Pielou equitability indices were higher in the Bocaina Stream $\left(\mathrm{H}^{\prime}=2.35, \mathrm{E}=0.65\right)$ than in the Água Comprida Stream $\left(\mathrm{H}^{\prime}=1.84, \mathrm{E}=0.55\right)$. In the case of the Shannon-Wiener diversity index, there was a significant difference between the values obtained for the two streams (Hutcheson t test, $\mathrm{p}<0.05$ ). The rarefaction curves for the two streams estimating richness through standardized abundance data are presented in figure 2. The Bocaina Stream has a higher richness than the Água Comprida Stream. The richness standardized for 4000 collected individuals was 33.25 taxa (30.40-36.10, 95\% confidence interval) for the Bocaina Stream and 28.46 taxa (27.11-29.82, 95\% confidence interval) for the Água Comprida Stream.

Figure 3 shows the ordination of the samples according to DCA. There was a clear separation between the Bocaina Stream and the Água Comprida Stream faunas. We can observe that, according to DCA I ( $87.6 \%$ of the total variance), the samples with higher scores were those collected in the Água Comprida Stream (Fig. 3). Caenis, Camelobaetidius, Gr. Traverhyphes, Xiphocentron, Gripopteryx, Farrodes, Baetodes, Chimarra, Grumicha, Cloeodes and Leptonema reached their optima in the Água Comprida Stream. On the other hand, Barypenthus, Macrogynoplax, Polyplectropus, Tricorythodes, Campylocia, Kempnyia, Hagenulopsis, Nectopsyche, Grumichella,

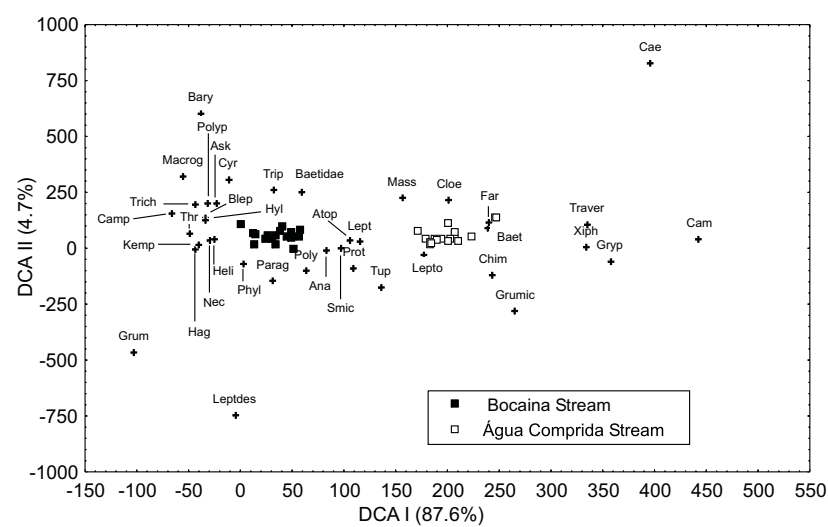

Figure 3. Scores of Detrended Correspondence Analysis (DCA) for samples and EPT taxa collected monthly from September 1999 to September 2000 and quarterly from December 2000 to September 2001 in Bocaina and Água Comprida Streams, Intervales State Park, São Paulo. Abbreviations table II.

Leptohyphodes, Helicopsyche, Thraulodes, Cyrnellus, Askola, Blepharopus, Hylister and Phylloicus reached their optima in the Bocaina Stream. The dendrogram (Fig. 4) representing the cluster analysis also confirms the clear separation between the faunas of the two streams.

The proportion of each functional feeding category for the two studied streams is presented in figure 5. In this figure, for the taxa belonging to more than one category, only the main alimentary behaviour was considered. In the Bocaina Stream, the scrapers category was dominant (49.35\%), followed by the collectors $(25.57 \%)$, shredders $(16.36 \%)$ and predators $(8.72 \%)$. In the Água Comprida Stream, the dominant category was the collectors (51.81\%) followed by the scrapers (45.76\%) with a 
Table II. Numbers of immatures of genera of Ephemeroptera, Plecoptera and Trichoptera collected monthly from September 1999 to September 2000 and quarterly from December 2000 to September 2001 in Bocaina and Água Comprida Streams, Intervales State Park, São Paulo.

\begin{tabular}{|c|c|c|c|c|c|}
\hline Genera & Abbreviations & Bocaina & Comprida & Total & Feeding Category \\
\hline Leptohyphes Eaton, 1882 & Lept & 243 & 150 & 393 & $\mathrm{CR}$ \\
\hline Gr.Traverhyphes Molineri, 2001 & Traver & 32 & 895 & 927 & C \\
\hline Tricorythodes Ulmer, 1920 & Trich & 3 & 0 & 3 & C \\
\hline Leptohyphodes Ulmer, 1920 & Leptdes & 2 & 0 & 2 & C \\
\hline Thraulodes Ulmer, 1920 & Thr & 1359 & 0 & 1359 & $\mathrm{R}, \mathrm{C}$ \\
\hline Hylister Domínguez \& Flowers, 1989 & Hyl & 333 & 3 & 336 & C \\
\hline Hagenulopsis Ulmer, 1919 & Hag & 292 & 1 & 293 & $\mathrm{C}$ \\
\hline Farrodes Peters, 1971 & Far & 38 & 158 & 196 & $\mathrm{R}, \mathrm{C}$ \\
\hline Massartella Lestage, 1930 & Mass & 22 & 30 & 52 & $\mathrm{R}, \mathrm{C}$ \\
\hline Askola Peters, 1969 & Ask & 1 & 0 & 1 & $\mathrm{R}, \mathrm{C}$ \\
\hline Baetodes Needham \& Murphy, 1924 & Baet & 108 & 1805 & 1913 & $\mathrm{R}$ \\
\hline Cloeodes Traver, 1938 & Cloe & 48 & 109 & 157 & C \\
\hline Camelobaetidius Demoulin, 1966 & Cam & 0 & 3 & 3 & C \\
\hline Others Baetidae & Baetidae & 49 & 15 & 64 & $\mathrm{C}$ \\
\hline Caenis Stephens, 1835 & Cae & 0 & 1 & 1 & C \\
\hline Campylocia Needham \& Murphy, 1924 & Camp & 104 & 0 & 104 & $\mathrm{~F}$ \\
\hline Anacroneuria Klapálek, 1909 & Ana & 422 & 84 & 506 & $P$ \\
\hline Kempnyia Klapálek, 1914 & Kemp & 218 & 1 & 219 & $P$ \\
\hline Macrogynoplax Enderlein, 1909 & Macrog & 11 & 0 & 11 & $P$ \\
\hline Tupiperla Froehlich, 1969 & Tup & 7 & 8 & 15 & C \\
\hline Gripopteryx Pictet, 1841 & Grip & 2 & 33 & 35 & CR \\
\hline Paragripopteryx Enderlein, 1909 & Parag & 64 & 11 & 75 & $\mathrm{CF}$ \\
\hline Leptonema Guérin, 1843 & Lepto & 246 & 798 & 1044 & $\mathrm{CP}$ \\
\hline Smicridea McLachlan, 1871 & Smic & 533 & 240 & 773 & C \\
\hline Blepharopus Kolenati, 1859 & Blep & 114 & 1 & 115 & C \\
\hline Phylloicus Müller, 1880 & Phyl & 69 & 5 & 74 & $\mathrm{~F}$ \\
\hline Nectopsyche Müller, 1879 & $\mathrm{Nec}$ & 1102 & 3 & 1105 & $\mathrm{~F}$ \\
\hline Triplectides Kolenati, 1859 & Trip & 15 & 2 & 17 & $\mathrm{~F}$ \\
\hline Grumichela Müller, 1879 & Grum & 1 & 0 & 1 & $\mathrm{CR}$ \\
\hline Helicopsyche Siebold, 1856 & Heli & 2337 & 39 & 2376 & $\mathrm{R}$ \\
\hline Chimarra Stephens, 1829 & Chim & 12 & 36 & 48 & $\mathrm{C}$ \\
\hline Polycentropus Curtis, 1835 & Poly & 3 & 1 & 4 & $\mathrm{CP}$ \\
\hline Polyplectropus Ulmer, 1905 & Polyp & 31 & 0 & 31 & C \\
\hline Cyrnellus Banks, 1913 & Cyr & 1 & 0 & 1 & C \\
\hline Atopsyche Banks, 1905 & Atop & 37 & 14 & 51 & $P$ \\
\hline Protoptilinae Ross, 1956 & Prot & 29 & 18 & 47 & $\mathrm{R}$ \\
\hline Xiphocentron Brauer, 1870 & Xiph & 1 & 12 & 13 & $\mathrm{C}$ \\
\hline Grumicha Müller, 1879 & Grumic & 1 & 4 & 5 & C \\
\hline Barypenthus Burmeister, 1839 & Bary & 1 & 0 & 1 & $P$ \\
\hline Ephemeroptera Total & - & 2634 & 3170 & 5804 & \\
\hline Plecoptera Total & - & 724 & 137 & 861 & \\
\hline Trichoptera Total & - & 4533 & 1173 & 5706 & \\
\hline Grand Total & - & 7891 & 4480 & 12371 & \\
\hline
\end{tabular}




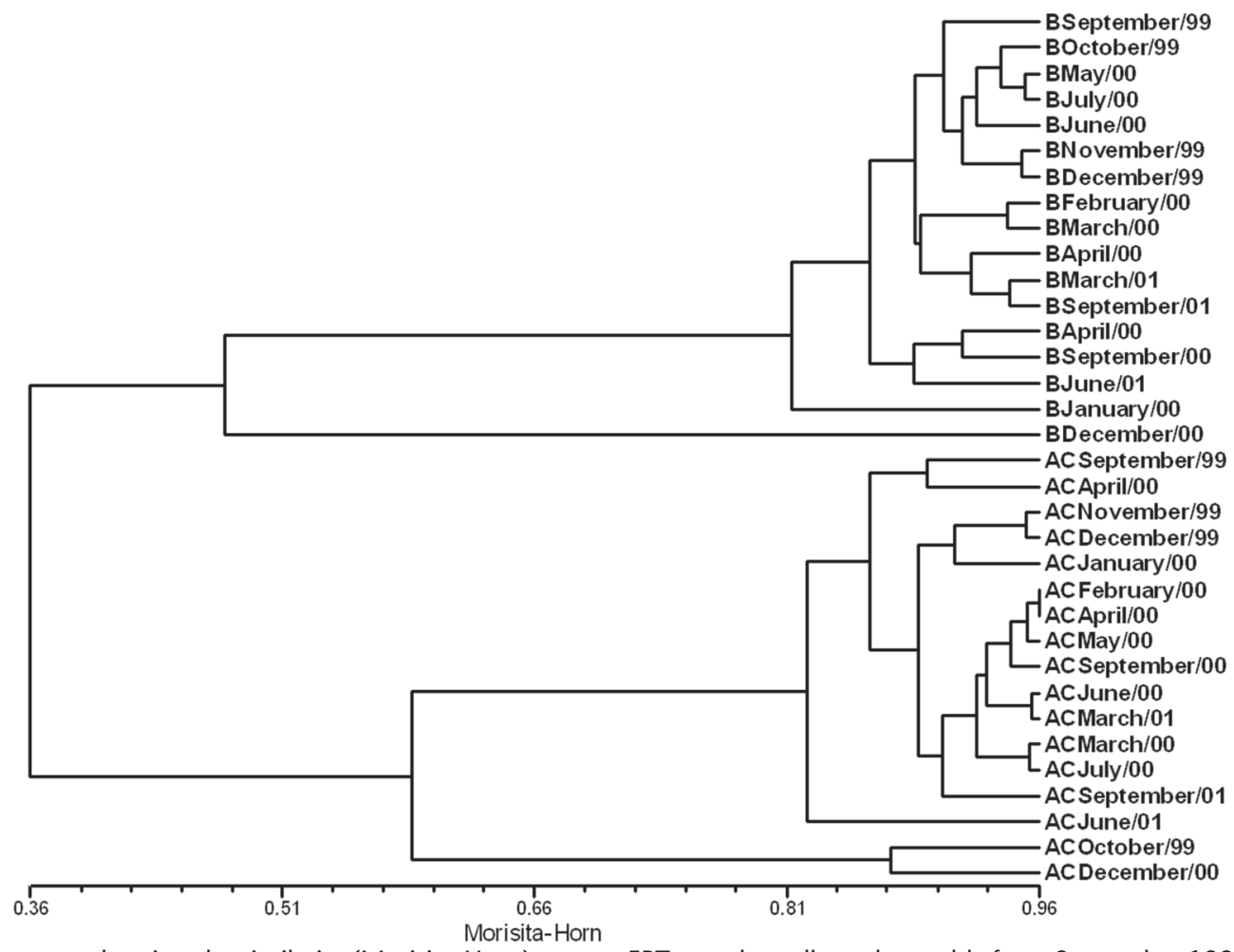

Figure 4. Dendrogram showing the similarity (Morisita-Horn) among EPT samples collected monthly from September 1999 to September 2000 and quarterly from December 2000 to September 2001 in Bocaina and Água Comprida Streams, Intervales State Park, São Paulo. Linkage: UPGMA. Cophenetic correlation coefficient $(0,929)$. B, Bocaina Stream; A, Água Comprida Stream.
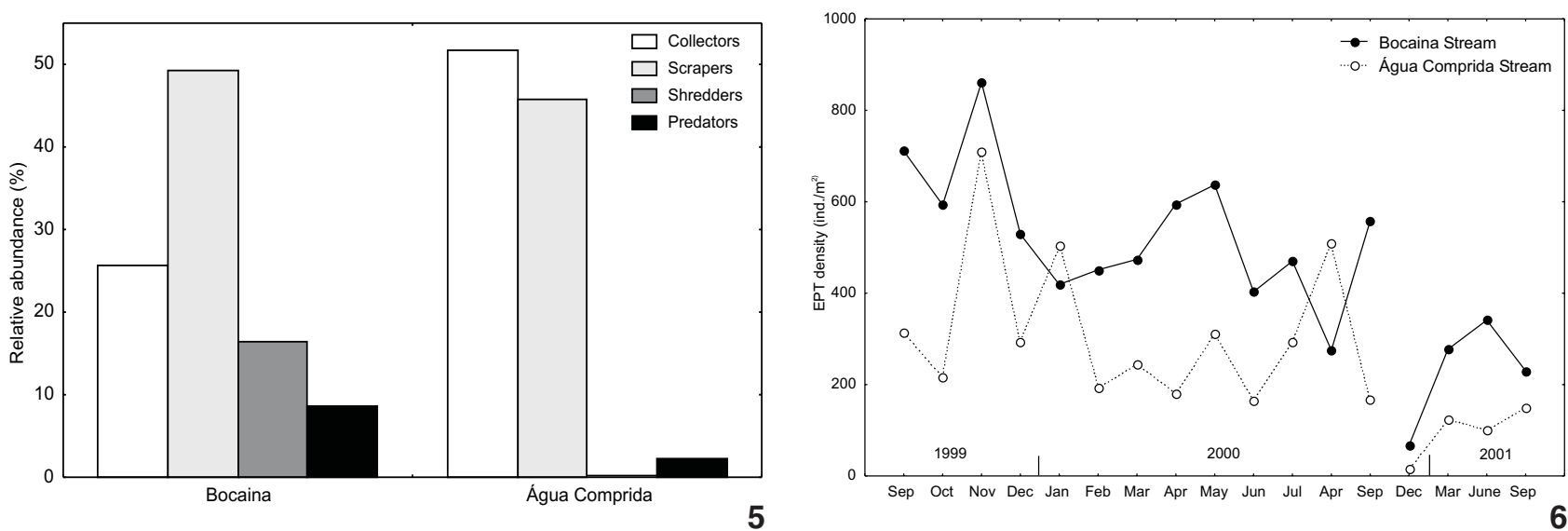

Figures 5-6. (5) Relative abundances (\%) of the functional feeding categories and (6) temporal variation in density of EPT collected monthly from September 1999 to September 2000 and quarterly from December 2000 to September 2001 in Bocaina and Água Comprida Streams, Intervales State Park, São Paulo.

quite low percentage of predators $(2.21 \%)$ and shredders $(0.22 \%)$.

Figure 6 shows the temporal variation of the EPT density for the two streams. In the Bocaina Stream, density peaks were observed in November (1999), May (2000) and September
(2000), while in the Água Comprida Stream the density peaks occurred in November (1999), January (2000) and August (2000). These results indicate that there was not a clear seasonal pattern in temporal variation of the EPT density. 


\section{DISCUSSION}

Ecological theory and empirical data have shown that environmental heterogeneity determines the taxon diversity in different communities. In that sense, a higher diversity of food resources (VANNOTE et al. 1980), a higher daily variation of temperature (VANNOTE et al. 1980) and a higher hydraulic variability (STATZNER \& Higler 1986) are some of the environmental heterogeneity sources that have constantly been mentioned as possible determinant factors of diversity as concerns aquatic organisms in lotic environments. Heterogeneous environments allow that a greater number of taxa manages to coexist in a given site. The data of this study indicate that environmental heterogeneity can be an explanation for the greater diversity of taxa registered in the Bocaina Stream. The higher environmental variability of the Bocaina Stream is promoted by good retention of litter between the rocks and the presence of riffles alternating with pools. On the other hand, the Água Comprida Stream has higher declivity and higher water speed, making it a highly erosive stream with low litter retention and in the studied stretch consisting almost only of riffles, making it a less variable environment than the Bocaina Stream.

The differences between the two streams were not reflected only in diversity but also in the composition of the fauna. The EPT community in the Bocaina Stream was formed by taxa that use rocky substrates or accumulations of litter retained by the rocks. Although the collections were made only in rocky substrate, taxa commonly associated with litter accumulations as Macrogynoplax, Campylocia, Nectopsyche and Phylloicus occurred preferentially in that stream. In the case of the Água Comprida Stream, the fauna had structured itself in a highly erosive environment.

The functional dynamics of the lotic environments influences directly the aquatic insect fauna, as it is related to the quality and availability of the food resources. Thus, in environments where the input of allochthonous energy in the form of coarse organic matter is predominant it is expected that shredders should have a greater importance. In sites where autochthonous energy inputs are important, scrapers should have greater importance. In general, collectors are always important for the functional dynamics of the stream, however the degree of their importance increases with increases in allochthonous energy inputs in the form of fine organic matter. The results of this study show that from the functional point of view the EPT communities have structured themselves in a different form in the two studied streams. In Bocaina Stream, where possibly there is a greater diversity of energy inputs (autochthonous and allochthonous) the functional categories were better equidistributed. In the the Água Comprida Stream, the collectors and scrapers were the dominant functional categories and the shredders are practically non-existent. That can be a reflection of the possible predominant autochthonous energy sources and of the low capacity of the studied stretch to retain allochthonous material due to the high speed of the water.
The temporal variation in the aquatic insect density can be determined by several factors, among them those related to the seasonal environmental changes, the capacity of recolonization after disturbance events, and life cycle characteristics among others. This study has not shown a clear seasonal pattern in the temporal variation in density; this result disagrees with other studies made in tropical regions in which abundance decreases in the rainy season were clearly observed (Boon et al. 1986, Flecker \& Feifarek 1994, Dudgeon 1996, 1997, Oliveira \& Froehlich 1997b, Bispo et al. 2004). These decreases can be related to environmental disturbances provoked by rain in certain periods of the year or by diminution of organism aggregation, due to rising of the water level in rainy periods. In this study, several falls in density were observed, and these falls cannot be explained by the rain seasonality, since the more rainy periods (January, February and March) in that region did not present lower densities when compared to the historically less rainy periods (May to September). The variations in density could be attributed to other possible factors as redistributions among patches, peaks of recruitment of immatures and peaks of adult emergence. The results of this paper showed that the different environmental conditions of the two studied streams determined differences in EPT diversity, faunistic composition and functional structure. On the other hand, it indicated that there was no clear seasonal pattern in the temporal variation of density.

\section{ACKNOWLEGMENTS}

Our thanks to the Zoology Museum of the University (USP) and to the administration of the Intervales State Park for the logistic support. VLCB thanks FFCLRP and CAPES for a grant for the development of this study. PCB thanks FAPESP (process 98/11074-3, 02/07216-4; 04/09711-8) and CNPq (process 473246/2004-0) for their support. PCB (process 301578/20044) and CGF (process 304554/2003-0) have productivity grants from CNPq. We also thank João da Cruz and Márcio Zanetti for their help in field work.

\section{REFERENCES}

Angrisano, E.B. 1995. Insecta Trichoptera, p. 1199-1224. In: E.C. Lopretto \& G. Tell (Eds). Ecosistemas de aguas continentales. Metodologias para su estudio. La Plata, Ediciones Sur, vol. 3, p. 897-1401.

BenEDETTO, L. 1974. Clave para la determinación de los plecopteros sudamericanos. Studies on Neotropical Fauna and Environment 9: 141-170.

Bıspo, P.C. \& L.G. Oliveira. 1998. Distribuição espacial de insetos aquáticos (Ephemeroptera, Plecoptera e Trichoptera), em córregos de cerrado do Parque Ecológico de Goiânia, Estado de Goiás, p. 175-189. In: J.L. Nessimian, \& A.C. Carvalho (Eds). Ecologia de insetos aquáticos. Rio de Janeiro, Série Oecologia Brasiliensis, PPGE-UFRJ, vol. 5, XVII+309p.

Bispo, P.C.; L.G. Oliveira; V.L. Crisci \& M.M. Silva. 2001. A pluviosidade como fator de alteração da entomofauna bentônica

Revista Brasileira de Zoologia 24 (2): 312-318, junho 2007 
(Ephemeroptera, Plecoptera e Trichoptera) em córregos do planalto central do Brasil. Acta Limnologica Brasiliensia 13 (2): 1-9.

Bispo, P.C.; L.G. Oliveira; V.L. Crisci-Bispo \& K.G. Sousa. 2004. Environmental factors influencing distribution and abundance of trichopterans in Central Brazilian mountain streams. Studies on Neotropical Fauna and Environment, Abingdon, 39 (3): 233-237.

Boon, P.J.; B.P. Jupp \& D.G. Lee. 1986. The benthic ecology of rivers in the Blue Mountains (Jamaica) prior to construction of a water regulation scheme. Archiv fur Hydrobiologie/ Supplement 74: 315-355.

Cummins, K.W. \& M.J. Klug. 1979. Feeding ecology of stream invertebrates. Annual Review of Ecology and Systematics 10: $147-172$.

Diniz-Filho, J.A.F.; L.G. Oliveira \& M.M. Silva. 1998. Explaining the beta diversity of aquatic insects in "cerrado" streams from Central Brazil using multiple Mantel Test. Revista Brasileira de Biologia 58 (2): 223-231.

Domínguez, E.; M.D. Hubbard \& W.L. Peters. 1992. Clave para ninfas y adultos de las familias y géneros de Ephemeroptera (Insecta) sudamericanos. Biología Acuática 16: 1-32.

Dudgeon, D. 1996. Life histories, secondary production and microdistribution of Heptageniidae mayflies (Ephemeroptera) in a tropical forest stream. Journal of Zoology 240: 341-361.

Dudgeon, D. 1997. Life histories, secondary production and microdistribution of hydropsychid caddisflies (Trichoptera) in a tropical forest stream. Journal of Zoology 243: 191-210.

Flecker, A.S. \& B. FeIfarek. 1994. Disturbance and temporal variability of invertebrate assemblages in two Andean streams. Freshwater Biology 31: 131-142.

Froehlich, C.G. 1984. Brazilian Plecoptera 4. Nymphs of perlid genera from southeastern Brazil. Annales de Limnologie 20 (1-2): 43-48.

Froehlich, C.G. \& L.G. Oliveira. 1997. Ephemeroptera and Plecoptera nymphs from riffles in low-order streams in southeastern Brazil, p. 180-185. In: P. LANDOLT \& M. SARTORI (Eds). Ephemeroptera and Plecoptera: biology-ecology-systematics. Fribourg, MTL, XI+596p.

Gotelli, N.J. \& G.L. Entsminger. 2000. EcoSim: null models software for ecology. Version 5.0. Available in the World Wide Web at: http://homepages.together.net/ gentsmin/ ecosim.htm [Accessed in 02.II.2002]

Horn, H.S. 1966. Measurement of "overlap" in comparative ecological studies. The American Naturalist 100 (914): 419-424.

Hulbert, S.H. 1971. The nonconcept of species diversity: a critique and alternative parameters. Ecology 52: 577-585.

KREBS, C.J. 1999. Ecological methodology. New York, Harper \& Row, XII+620p.

LIND, O.T. 1979. Handbook of common methods in limnology. London, The C.V. Mosby, XI+199p.

MAGURRAN, A.E. 1989. Ecological diversity and it's measurement. London, Chapmam \& Hall, 179p.
Marchant, R; L.A. Barmuta \& B.C. Chessman. 1995. Influence of sample quantification and taxonomic resolution on the ordination of macroinvertebrate communities from running waters in Victoria, Australia. Marine \& Freshwater Research 46: 501-506.

McCune, B. \& M.J. MEFFord. 1999. PC-ORD. Multivariate analysis of ecological data. Oregon, MjM Software Design, version 4.0.

Merritt, R.W. \& K.W. Cummins. 1996. An Introduction to the aquatic insects of North America. Dubuque, Kendall/Hunt Publishing, $3^{\text {rd }}$ ed., XIII+862p.

Navas-Pereira, D. \& R.M. Henrique. 1996. Aplicação de índices biológicos numéricos na avaliação da qualidade ambiental. Revista Brasileira de Biologia 56 (2): 441-450.

Oliveira, L.G. \& C.G. Froehlich. 1997a. Diversity and community structure of aquatic insects (Ephemeroptera, Plecoptera and Trichoptera) in a mountain stream in Southeastern Brazil. Acta Limnologica do Brasiliensia 9: 139-148.

Oliveira, L.G. \& C.G. Froehlich. 1997b. The Trichoptera (Insecta) fauna of a "cerrado" stream in Southeastern Brazil. Naturalia 22: 183-127.

Oliveira, L.G.; P.C. Bispo \& N.C. Sá. 1997. Ecologia de comunidades de insetos aquáticos (Ephemeroptera, Plecoptera e Trichoptera), em córregos de cerrado do Parque Ecológico de Goiânia, Goiás, Brasil. Revista Brasileira de Zoologia 14 (4): 867-876.

Polegatto, C.M. \& C.G. Froenlich. 2003. Feeding strategies in Atalophlebiinae (Ephemeroptera: Leptophlebiidae), with considerations on scraping and filtering, p. 55-61. In: E. GAINO (Ed.) Research update on Ephemeroptera and Plecoptera. Perugia, University of Perugia, 488p.

RoHLF, F.J. 2000. NTSYS 2.1: numerical taxonomic and multivariate analysis system. New York, Exeter Software.

Romesburg, H.C. 1984. Cluster analysis for researchers. Malabar, Robert E. Krieger Publishing, XV+334p.

Rosenberg, D.M. \& V.H. Resh. 1993. Freshwater biomonitoring and benthic macroinvertebrates. London, Chapman and Hall, IX+488p.

SimberlofF, D. 1972. Properties of the rarefaction diversity measurement. The American Naturalist 106: 414-418.

Statzner, B. \& B. Higler. 1986. Stream hydraulics as a major determinant of benthic invertebrate zonation patterns. Freshwater Biology 16: 127-139.

Strahler, H.N. 1957. Quantitative analysis of watershed geomorphology. American Geophysics Union Transactions 33: 913920.

Vannote, R.L.; G.W. Minshall; K.W.L. Cummins; J. R. Sedell \& C. E. Cushing. 1980. The River Continuum Concept. Canadian Journal Fisheries and Aquatic Sciences 37: 130-137.

Wiggins, G.B. 1998. Larvae of the North America Caddisfly Genera (Trichoptera). Toronto, University of Toronto Press, $2^{\text {nd }}$ ed., IX+457p.

Received in 28.VII.2006; accepted in 28.IV.2007. 